\title{
A Study on the Factors Influencing Graduates' Employment
}

\author{
Jung-Eun Heo1), Li Xiaohui2)
}

\begin{abstract}
In this document we will examine the employment decision factors by analyzing the effect of gender, age, major (a minor or double major), length of study, in the employment of graduates for February and August of 2017. The result is as follows: First, it shows that gender can make a difference in employment, and men have more influence in the employment possibility than women. Second, the factor of age has no significant effect on employment. Next, the factor of majors in the order of medicine \& nursing, engineering, and education influences to increase employment possibility. Subsequently, this period of study shows the highest possibility of employment in a period of 4 to 6 years. Finally, a minor or double major has no significant effect comprehensively. The detailed analysis result shows that a minor or double major could help in employment in some way. Based on the results, the following suggestions can be made, such as improving the recruitment system according to their abilities rather than gender; also considering employment programs and policies to help graduates who majored in humanities, social sciences, and so forth.
\end{abstract}

Keywords : Graduates, Employment, Determinant, Influencing, Decision

\section{Introduction}

Compared with high school, the aim of a college education is to cultivate professionals who have the competency required by society for providing students with a deeper level of knowledge and problem-solving ability as result of the curriculum. Recently, because of the popularization of college entrance exams, the role of academic universities in the past has been emphasized in terms of the industry-academic link, and the functions of universities have changed in a complex way. The employment rate of university graduates has been declining for five consecutive years. The unemployment rate of college students who graduated in 2018 is $18.3 \%$ and the sensory unemployment rate is $40.2 \%$ (Daily U's Line, 2018)[1]. Lately, it is

Received(April 24, 2019), Review Result(1st: May 17, 2019, 2nd: July 11, 2019), Accepted(September 10, 2019)

1) (Ph.D. course) 46241 Admission Department of Pusan Nation University, Pusan National University, 2, Busandaehak-ro 63, Geumjeong-gu, Busan, Korea

email: odryje@hanmail.net

2) (Ph.D. course, Corresponding Author) 46241 Dept. of Education, Pusan National University, 2, Busandaehak-ro 63, Geumjeong-gu, Busan, Korea

email: lixiaohui2016@naver.com 
difficult for university graduates to find jobs and the employment rate is also recognized as one of the important achievements of university education. Universities are increasingly responsible for attracting talent that meets their educational goals, providing a university experience that is favorable to their jobs, increasing their employment rate, and linking them to the desired employment of the student.

In this study, we selected P University graduates who graduated in February and August 2017 as analysis subjects and analyzed the effects of gender, age, major, minor or double major, the length of study of graduate employment. We hope that universities could take full advantage of this study in the aspect of utilizing the policy for employment, and improving efficiency in school management and so on.

In order to achieve this purpose, two questions were set up as follows.

First, how is the employment status of graduates by gender, age, major, the length of study, and minor or double major?

Second, which factors could affect graduates' employment?

\section{Review of Previous Study}

In order to improve the quality of education, many scholars have worked hard by analyzing the effect of college graduates on employment. In South Korea, the university entrance system has undergone a lot of changes, and studies of university life satisfaction and academic achievement analysis have been conducted by universities. On the other hand, there are more and more studies that reveal the relationship between university life experience and employment. Some studies have emphasized the need to listen to industry demands and reflect them in the educational form (M.S. Jin, 2012)[2], others have clarified university life experience as employment preparation activities to figure out the relationship to employment (S. M. Shin, 2013; H. B. Park \& S. S. Kim, 2011; G. R. Roh, 2011)[3]. These studies are limited to trying to grasp college life satisfaction and factors of social advance centered on credit.

The factors that determine the employment of graduates are affected by many complex factors. Looking through previous studies related to determinants of graduates' employment rate, T. Y. Jeong \& G. Y. Lee Giyeop (2005) have investigated the determinants of graduates' employment rate focusing on the effect of credit[4]. According to S. Y. Oh (2003), compared with females, employment rates of males in the major of science and engineering is much higher than that of non-science and engineering, and the employment rate is high with decreasing age[5]. The employment possibility of graduates in the major of medicine, 
engineering, and nature is much higher than that of humanities(C. G. Chae \& T. G. Kim, 2009; G. Y. Choe \& B. S. Kim, 2016)[6]. J. S. Joe (2011) has shown that there is a positive correlation between foreign language scores and employment rate, and the type of admission makes no difference to the employment rate[7].

The problem of these previous studies is using the results of the self - filling questionnaire survey, but in this study, we tried to increase the reliability of the data by utilizing $\mathrm{P}$ university employment strategy and the 2017 graduate employment data. In addition, we tried to supplement the empirical research with objective data such as gender, age, major, minor or double major, the length of study, excluding subjective data such as parents' social and economic background and school life satisfaction.

\section{Research Method}

\subsection{Research Object}

In this study, 3,935 university graduates (excluding advanced graduates, military entrepreneurs, immigrants, and fatalities) were selected for research in February and August of 2017 with the aim of identifying the factors affecting the employment of graduates.

\subsection{Defining and Coding Variables}

The factors affecting the employment of graduates are divided into internal factors and external factors[8]. In this study, we defined gender and age as internal factors and major, the period of study, a minor or double major as external factors. For statistical analysis, gender was classified into males by 1 and females by 2. Based on January 1, 2019, the age group was classified as 25 years old or younger, 26 to 29 years old, and 30 years old or older, and endowed with $1 \sim 3$.

The major divisions were classified into humanities by 1 , social studies by 2 , economics by 3 , education by 4 , engineering by 5 , nature by 6 , agriculture by 7 , medicine\&nursing by 8 and art \& sport by 9 . The period of study was based on the year of enrollment and graduation, and was classified as 4 years or less, 4 to 6 years, 6 to 8 years, or 8 years or more, and endowed with 1 4 for statistical analysis. As for a minor or double major, we classified "with $i t^{\prime \prime}$ by 1 and "without it" by 2 . It is expected that the variables of employment-related credit could be influential, but they are excluded from the variables for analyzing employment due to 
the difficulty of accepting personal information in the graduation credit information.

\subsection{Analysis Method}

This study used cross-tab analysis and logistic regression. We used crossover analysis to find out how the employment situation differs according to each independent variables and analyzed the determinants of the employment of college graduates through logistic regression analysis[9].

\section{Results}

\subsection{Employment Status by Independent Variables}

Though cross-tab analysis, employment status by independent variables such as gender, age, major, the period of study, a minor or double major is shown in [Table 1][10].

The total employment rate for graduates was $50.39 \%$ and the unemployment rate is $49.61 \%$. In terms of gender, the male employment rate is $58.71 \%$, which is higher than female $41.28 \%$. $52.83 \%$ of male employees were in the major of engineering, while $16.34 \%$ of female employees were in the major of engineering.

As for age, in the age group of 25 years old or younger, the percentage of employed persons $(42.98 \%)$ is lower than that of unemployed persons $(57.02 \%)$. In the age group of 26 to 29 years old, the ratio of employed persons $(55.40 \%)$ is higher than that of unemployed persons $(44.60 \%)$. In the age group of 30 years old or older, the ratio of employed persons $(49.67 \%)$ is lower than that of the unemployed $(50.33 \%)$.

In terms of major, the employment rate of those majoring economics, engineering, medicine\&nursing is higher than that in the unemployed. And the employment rate of those in the one a major of humanities, social studies, education, nature, agriculture, art\&sport is lower than that of the unemployed.

In respect of the length of study, the ratio of employed graduates (58.16\%) is higher than that of unemployed graduates $(41.84 \%)$ in the period of $6 \sim 8$ years, which is completely opposite with 4 years or less, $4 \sim 6$ years, 8 years or more.

In the aspect of a minor or double major, among the 3,935 graduates, the ratio of female students with a minor or double major (56.74\%) is higher than that of male students $(43.26 \%)$. The employment rate of graduates with a minor or double major $(45.97 \%)$ is lower than that of 
Vol.5, No.3, September 30 (2019), pp. 81-89 http://dx.doi.org/10.21742/apjcri.2019.09.09 unemployed graduates $(54.03 \%)$, and the employment rate of graduates without minor or double major $(52.23 \%)$ is higher than that of unemployed graduates (47.78\%). Among the 3,935 graduates, the rate of students with a minor or double major is $27.14 \%$ (1,068 students). Among them, the rate of females with a minor or double major $(56.74 \%)$ is higher than that of males (43.26\%). And there are students attending both minor and double major.

The rate of minor or double major in the social sciences $(18.63 \%)$ is the highest among the total students with a minor or double major, followed by students with a minor or double major in economics $(11.61 \%)$.

[Table 1] Employment Status by Independent Variables (Units :\%)

\begin{tabular}{|c|c|c|c|c|c|c|}
\hline Factors & Variable & Classification & Employed(\%) & $\begin{array}{c}\text { Unemployed } \\
(\%)\end{array}$ & \multicolumn{2}{|c|}{ Total(\%) } \\
\hline \multirow{5}{*}{$\begin{array}{l}\text { Internal } \\
\text { factors }\end{array}$} & \multirow{2}{*}{ Gender } & male & $1200(58.71)$ & $844(41.29)$ & $2044(100.00)$ & \multirow{2}{*}{$\begin{array}{c}x 2=117.62 \\
d f=1 \\
p=.000\end{array}$} \\
\hline & & female & $783(41.28)$ & $1108(58.59)$ & 1891(100.00) & \\
\hline & \multirow{3}{*}{ Age } & 25 years or younger & $621(42.98)$ & $824(57.02)$ & $1445(100.00)$ & \multirow{3}{*}{$\begin{array}{c}x 2=53.79 \\
d f=2 \\
p=.000\end{array}$} \\
\hline & & 26 to 29 years old & $1210(55.40)$ & $974(44.60)$ & $2184(100.00)$ & \\
\hline & & 30 years old or older & $152(49.67)$ & $154(50.33)$ & $306(100.00)$ & \\
\hline \multirow{15}{*}{$\begin{array}{l}\text { External } \\
\text { factor }\end{array}$} & \multirow{9}{*}{ Major } & humanities & $214(42.46)$ & $290(57.54)$ & $504(100.00)$ & \multirow{9}{*}{$\begin{array}{c}x 2=427.83 \\
d f=8 \\
p=.000\end{array}$} \\
\hline & & social studies & $124(37.35)$ & $208(62.65)$ & 332(100.00) & \\
\hline & & economics & $274(54.47)$ & $229(45.53)$ & $503(100.00)$ & \\
\hline & & education & $70(22.22)$ & $245(77.78)$ & $315(100.00)$ & \\
\hline & & engineering & $858(66.25)$ & $437(33.75)$ & $1295(100.00)$ & \\
\hline & & nature & $125(35.11)$ & $231(64.89)$ & $356(100.00)$ & \\
\hline & & agriculture & $117(46.25)$ & $136(53.75)$ & $253(100.00)$ & \\
\hline & & medicine\&nursing & 132(88.59) & $17(11.41)$ & 149(100.00) & \\
\hline & & art\&sport & $69(30.26)$ & $159(69.74)$ & $228(100.00)$ & \\
\hline & \multirow{4}{*}{$\begin{array}{l}\text { The } \\
\text { length of } \\
\text { study }\end{array}$} & 4 years or less & $389(45.23)$ & $471(54.77)$ & $860(100.00)$ & \multirow{4}{*}{$\begin{array}{c}x 2=47.35 \\
d f=3 \\
p=.000\end{array}$} \\
\hline & & 4 to 6 years & $756(47.64)$ & $831(52.36)$ & 1587(100.00) & \\
\hline & & 6 to 8 years & $745(58.16)$ & $536(41.84)$ & $1281(100.00)$ & \\
\hline & & 8 years or more & $93(44.93)$ & $114(55.07)$ & $207(100.00)$ & \\
\hline & \multirow{2}{*}{$\begin{array}{c}\text { Minor or } \\
\text { double } \\
\text { major }\end{array}$} & with it & $531(45.97)$ & $624(54.03)$ & $1155(100.00)$ & \multirow{2}{*}{$\begin{array}{c}x 2=12.78 \\
d f=1 \\
p=.000\end{array}$} \\
\hline & & without it & $1452(52.23)$ & $1328(47.78)$ & $2780(100.00)$ & \\
\hline \multicolumn{3}{|c|}{ Total } & 1983(50.39) & 1952(49.61) & $3935(100.00)$ & \\
\hline
\end{tabular}




\subsection{Influencing Factors of Employment}

The result of the influencing factors of employment is shown in [Table 2]. As we can see, there is a significant effect on the employment status in gender, major in economics, education, engineering, medicine\&nursing, art\&sport, the length of study of study (4 6 years, $6 \sim 8$ years).

Analysis of the magnitude of influence by variables on the basis of the exponentiation ratio Exp (B) of the independent variables revealed that the employment rate of males is about 1.7 times higher than that of females. As for major, taking humanities as a reference category, the exponentiation ratio $\operatorname{Exp}(\mathrm{B})$ is in order of education (2.622), art\&sport (1.564), nature (1.469)[11].

A comparison of the relative magnitudes (Wald) of the influences on the dependent variables of each independent variables showed that they have a higher effect in the order of medicine\&nursing major, engineering major, gender, education major, economics major, 4 6 years of study.

[Table 2] Logistic Regression Result of Employment Influencing Factors

\begin{tabular}{|c|c|c|c|c|c|c|c|}
\hline \multicolumn{2}{|r|}{ Variable } & B & S.E. & Wald & $\mathrm{df}$ & sig. & $\operatorname{Exp}(B)$ \\
\hline \multicolumn{2}{|r|}{ Gender } & .541 & .092 & 34.334 & 1 & $.000^{*}$ & 1.717 \\
\hline \multirow{3}{*}{ Age } & $\begin{array}{l}25 \text { years or } \\
\text { younger }\end{array}$ & \multicolumn{6}{|c|}{ reference category } \\
\hline & 26 to 29 years old & -.277 & .161 & 2.969 & 1 & .085 & .758 \\
\hline & $\begin{array}{c}30 \text { years old or } \\
\text { older }\end{array}$ & -.226 & .146 & 2.393 & 1 & .122 & .798 \\
\hline \multirow{9}{*}{ Major } & humanities & \multicolumn{6}{|c|}{ reference category } \\
\hline & social studies & .276 & .147 & 3.542 & 1 & .060 & 1.318 \\
\hline & economics & -.383 & .129 & 8.778 & 1 & $.003 *$ & .682 \\
\hline & education & .964 & .168 & 33.110 & 1 & $.000 *$ & 2.622 \\
\hline & engineering & -.742 & .120 & 38.218 & 1 & $.000^{*}$ & .476 \\
\hline & nature & .385 & .147 & 6.830 & 1 & $.009^{*}$ & 1.469 \\
\hline & agriculture & -.040 & .161 & .062 & 1 & .804 & .961 \\
\hline & medicine\&nursing & -2.632 & .286 & 84.936 & 1 & $.000^{*}$ & .072 \\
\hline & art\&sport & .447 & .177 & 6.413 & 1 & $.011^{*}$ & 1.564 \\
\hline \multirow{4}{*}{$\begin{array}{l}\text { The } \\
\text { length of } \\
\text { study }\end{array}$} & 4 years or less & \multicolumn{6}{|c|}{ reference category } \\
\hline & 4 to 6 years & -.268 & .099 & 7.260 & 1 & $.007^{*}$ & .873 \\
\hline & 6 to 8 years & -.263 & .119 & 4.891 & 1 & $.027^{*}$ & .668 \\
\hline & 8 years or more & .136 & .182 & .558 & 1 & .455 & .671 \\
\hline \multicolumn{2}{|c|}{ Minor or double major } & .047 & .083 & .314 & 1 & .575 & 1.048 \\
\hline \multicolumn{2}{|r|}{ Constant } & -.534 & .257 & 4.306 & 1 & .038 & .586 \\
\hline
\end{tabular}


Vol.5, No.3, September 30 (2019), pp. 81-89 http://dx.doi.org/10.21742/apjcri.2019.09.09

According to the above results, although whether graduates had minor or double majors or not, it doesn't show a significant influence, in order to fully tap the factor of minor or double major, we affirmed what majors or departments graduates preferred to choose as their minor or double major; and explored how minor or double major might make a difference in employment. The result is shown in [Table 3] below. Compared with graduates who didn't have a minor or double major, a minor or double major in economics and nature shows a significant influence in the employment rate indeed. But the exponentiation ratio Exp (B) of economy is lower than 1 , which means that a minor or double major in economy shows lower influence.

[Table 3] Logistic Regression Result of Minor or Double Major (without Minor or Double Major as a Reference Category)

\begin{tabular}{|c|c|c|c|c|c|c|c|}
\hline \multirow{2}{*}{\multicolumn{2}{|c|}{$\begin{array}{c}\text { Classification } \\
\text { Without a minor or double major }\end{array}$}} & B & S.E. & Wald & $\mathrm{df}$ & sig. & $\operatorname{Exp}(\mathrm{B})$ \\
\hline & & \multicolumn{6}{|c|}{ reference category } \\
\hline \multirow{8}{*}{$\begin{array}{l}\text { With } \\
\text { minor or } \\
\text { double } \\
\text { major }\end{array}$} & Humanities & .184 & .168 & 1.196 & 1 & .274 & 1.202 \\
\hline & Social studies & .101 & .128 & .620 & 1 & .431 & 1.106 \\
\hline & Economics & -.402 & .118 & 11.555 & 1 & .001 & .669 \\
\hline & Education & .041 & .329 & .016 & 1 & .900 & 1.042 \\
\hline & Engineering & -.036 & .232 & .024 & 1 & .877 & .965 \\
\hline & Nature & .686 & .344 & 3.977 & 1 & .046 & 1.986 \\
\hline & Agriculture & .177 & 1.011 & .031 & 1 & .861 & 1.194 \\
\hline & Art\&sport & 1.552 & 1.154 & 1.808 & 1 & .179 & 4.719 \\
\hline
\end{tabular}

${ }^{*} \mathrm{p}<.05$

Only considering graduates who had minor or double majors and taking a minor or double major in humanities as a reference category, a minor or double major in economics shows a significant influence, but the exponentiation ratio Exp (B) is .589, lower than 1 , which means it has less influence relatively.

[Table 4] Logistic Regression Result of Minor or Double Major (Minor or Double Major in Humanities as a Reference Category)

\begin{tabular}{|c|c|c|c|c|c|c|}
\hline Classification & B & S.E. & Wald & df & sig. & Exp(B) \\
\hline Humanities & \multicolumn{7}{|c|}{ reference category } \\
\hline Social studies & -.020 & .194 & .010 & 1 & .919 & .980 \\
\hline Economic & -.530 & .188 & 7.948 & 1 & .005 & .589 \\
\hline Education & .189 & .388 & .237 & 1 & .626 & 1.208 \\
\hline
\end{tabular}




\begin{tabular}{|c|c|c|c|c|c|c|}
\hline Engineering & -.526 & .298 & 3.107 & 1 & .078 & .591 \\
\hline Nature & .267 & .389 & .470 & 1 & .493 & 1.305 \\
\hline Agriculture & -.310 & 1.083 & .082 & 1 & .775 & .734 \\
\hline Art\&sport & 1.440 & 1.157 & 1.549 & 1 & .213 & 4.220 \\
\hline
\end{tabular}

${ }^{*} \mathrm{p}<.05$

\section{Conclusion}

This study has analyzed the effects of sex, age, major, the period of study, a minor or double major on the employment of P university graduates in 2017. The result is as follows:

First, it shows that gender can make a difference in employment, and men have more influence on the employment possibility than women. The employment rate of engineering male students $(52.83 \%)$ is the highest among males, while the employment rate of humanities and social studies of female students $(23.74 \%)$ is the highest among females. In other words, it is found that the difference in preference for entering the labor market leads to a difference in employment possibility by gender.

Next, age does not have a significant effect on employment.

Subsequently, it is found that major in the order of medicine\&nursing, engineering, and education major influences to increase employment possibility. Most of these majors are graduates of college and major in acquiring professional qualifications. In other words, it can be confirmed that acquiring the certificate related to the major facilitates high-quality workplace employment.

The period of the study has shown the highest possibility of employment in the period of 4 years to 6 years. The longer the period of study, the lower the possibility of employment.

Finally, although with or without a minor or double major has no significant effect comprehensively, the detailed analysis result shows that with a minor or double major in nature could help in employment in some way. In general, it can be seen that the employment decision is based on one's major rather than a minor or double major.

Based on the results of the analysis of employment factors of graduates, the following suggestions can be made. It will be necessary to improve the recruitment system so that female college graduates can be recruited according to their abilities rather than gender. The employment rate in the natural sciences centered on engineering majors is higher than that in the humanities and social sciences, so employment programs and policies should be considered to improve the employment rate of the majors of humanities and social sciences. As the length 
of school enrollment decreases, the possibility of employment becomes lower. Therefore, it is more effective to prepare for social advancement through a tailored employment preparation program for each job within the school term rather than by extension of school enrollment through the graduation retirement system.

\section{References}

[1] http://www.usline.kr/news/articleView.html?idxno=11167, Apr 23 (2018)

[2] Misug Jin, Youmi Son, Changyong Song, The study of Creative Career Development Program effect, The Journal of Career Education Research, (2012), Vol.25, No.1, pp.165-185, UCI: G704-001285.2012.25.1.009

[3] Soo-Kyung Kim, The effects of the college admitted type of students on the college life experience and the employment, Journal of Employment and Career, (2016), Vol.6, No.3, pp.1-20, DOI: 10.35273/jec.2016.6.3.001

[4] Tae Young Jung, Key Yab Lee, Determinants of Job Finding among College Graduates: with Emphasis on the Effects of GPA, Korea Business Review, (2005), Vol.8, No.2, pp.159-184, UCI: G704-001117.2005.8.2.001

[5] Oh, Se gyu, (An) Analysis of the determinents of youth employment probability in Korea, Yonsei University, Master Thesis, (2003)

[6] Dong-ki Yum, Sang-kyu Moon, Sung-su Park., An Empirical Study on the Determinants of Employment Outcomes of University Graduates, Journal of Employment and Career, (2017), Vol.7, No.4, pp.45-68, DOI: 10.35273/jec.2017.7.4.003

[7] Cho Jang-Sik, Determinants of job finding using student's characteristic information, Journal of the Korean Data And Information Science Sociaty, (2011), Vol.22, No.5, pp.849-856, UCI: G704-000605.2011.22.5.017

[8] Hye jin Kwon, Dohee Kwon, ihye Ahn, Examining Factors Related to University Graduates' Employment Focusing on Experiences both Inside and Outside the University, The educaitonal Research for Tomorrow, (2010), Vol.23, No.2, pp33-57.

[9] Man-Ki Lee, Ho-Won Kim, The effect of employment preparation activities influencing on the decent job of college graduates, Journal of Employment and Career, (2015), Vol.5, No.4, pp.115-138, DOI: 10.35273/jec.2015.5.4.005

[10] Il Soo Choi, Eunjong Shin, An Empirical Study of the Determinants of Successful Job Seeking of College Students -Focusing on the Impacts of Job Education Programs, The Korean Journal of Economic Education, (2016), Vol.23, No.1, pp.23-49, UCI: G704-001911.2016.23.1.001

[11] Byoung-Joo Kim, Hwa-Joung Seo, Analysis on Student and University Variables Affecting First Employment of College Graduates, The Journal of economics and finance of education, (2013), Vol.22, No.4, pp.243-268, UCI: G704-000105.2013.22.4.004 